\title{
Opportunities and threats for natural building using straw bale technology
}

\author{
Agnieszka Augustyńska \\ Department of Building Engineering and Building Physics; Faculty of Civil Engineering, \\ Architecture and Environmental Engineering; \\ UTP University of Sciences and Technology; Profesora Sylwestra Kaliskiego 7, 85-796 Bydgoszcz, Poland; \\ agnieszka.augustynska@utp.edu.pl (DD 0000-0001-6676-3498
}

\begin{abstract}
In this paper, the possibilities of using straw bale technology in construction, as well as the threats that limit both its development and dissemination, have been presented. This study has also investigated the use of recyclable waste and the role of recycling in natural construction, as well as the impact of $\mathrm{CO}_{2}$ reduction on pro-ecological activities. The characteristics of natural straw construction have been discussed, and the main features of straw bale technology have been presented. Examples of the implementation of straw bale technology in both Poland and Europe have been presented and the methods of their use have been described. An integral part of this study is an overview of the opportunities and threats of the use of straw bale technology in natural construction. Low-emission technologies using biodegradable materials as well as the possibility of building nZEB and passive buildings are indicated as main advantages of the technology.

The necessity of introducing legal regulations that would enable the development of natural construction using straw bale technology was indicated. Straw bale technology was created as a response to an ecological challenge for sustainable construction and has significant innovation potential.
\end{abstract}

Keywords: straw bale, natural construction, natural materials, low energy construction, recycling, $\mathrm{CO}_{2}$ emission

\section{Introduction}

Straw has been used as a construction material for centuries; it has been used in thatched roofs, for sealing the walls of wooden structures, for filling half-timbered buildings and also for the production of clay-straw bricks [1]. At the end of the nineteenth century, a new application was found for cubes of compressed straw; known throughout the world as straw bales. American settlers in the state of Nebraska were the first in the world to use straw for construction purposes. In Europe, the oldest house that was built using straw bale technology 
dates from 1921 and is located in France [1]. The possibilities for the use of straw cubes are extensive, from filling wooden constructions (Infill) and insulating existing buildings, to the prefabrication of wooden-straw panels.

Straw is a byproduct of farming, i.e. it is agricultural waste from grain threshing; it is obtained in a renewable manner on an annual basis. Every year in Poland 25 million tons of this raw material are produced, which would potentially allow for the construction of thousands of ecological, energy-saving buildings. Realistic straw surplus forecasts indicate that there will be a slow reduction in the surplus to around 10 million tons in 2030 [2]. At present, a lot of attention is focused on the design of buildings with reduced primary energy demand and a low operating cost [1].

A straw cube, the equivalent of the English term 'straw bale', is created by mechanical compression of straw through a square baler and it is then tied with string or wire. Depending on the type of press used, it is possible to obtain cubes of different sizes; three groups of cube size are distinguished:

- small - height $35 \mathrm{~cm}$, width $50 \mathrm{~cm}$, length $50-120 \mathrm{~cm}$,

- medium - height $50 \mathrm{~cm}$, width $80 \mathrm{~cm}$, length $70-240 \mathrm{~cm}$,

- jumbo - height $70 \mathrm{~cm}$, width $120 \mathrm{~cm}$, length 120-300 cm [3].

In order to construct walls, small cubes are most often used due to their light weight and the possibility of manual positioning, negating the need for heavy equipment [1]. Table 1 presents selected parameters of compacted straw bales.

Table 1. Selected parameters of a straw cube with dimensions of $40 \times 47.5 \times 100 \mathrm{~cm}$

\begin{tabular}{lll}
\hline 1 & volume, $\mathrm{V}$ & $0.19 \mathrm{~m}^{3}$ \\
\hline 2 & unit price & $2-5 \mathrm{PLN} / \mathrm{unit}$ \\
\hline 3 & straw consumption standard & $5 \mathrm{cubes}^{2} / \mathrm{m}^{3}$ \\
\hline & $\begin{array}{l}\text { thermal conductivity coefficient, } \lambda \\
\text { (for cubes of pressed straw with a density of } 85-115 \mathrm{~kg} / \mathrm{m} 3 \text { and a heat flux direction } \\
\text { parallel to the fibres) }\end{array}$ & $0.080 \mathrm{~W} /(\mathrm{mK})$ \\
\hline & $\begin{array}{l}\text { thermal conductivity coefficient, } \lambda \\
\text { (for cubes of pressed straw with a density of } 85-115 \mathrm{~kg} / \mathrm{m} 3 \text { and a heat flux direction } \\
\text { perpendicular to the fibres; this arrangement does not apply to straw bale technology) }\end{array}$ & $0.052 \mathrm{~W} /(\mathrm{mK})$ \\
\hline
\end{tabular}

\section{The importance of using straw bale technology in the construction industry}

\subsection{Recycling and sustainability for the construction sector}

According to the Central Statistical Office, in Chapter 2 'Use of recyclable waste' of the statistical analysis 'Material management' 2017, recyclable waste is a useful waste material that is generated during production processes, as well as waste products and pre-sorted municipal waste fractions (without processing) that are not suitable for direct use in industrial processing. These days, both ecological and economic aspects have had a major impact on the growing interest in the use of waste products. This is closely related to environmental protection, i.e. limiting greenhouse gas emissions and water pollution, and, to a large extent, limiting energy consumption during production. The Central Statistical Office of Poland emphasizes that it is observing clear trends in the recovery of materials and their use as an environmentally 
friendly secondary raw material [4]. In light of the quantitative data that was presented in the literature, the search for building materials that can contribute to the sustainable development of construction is an important goal, which has also been set out by the European Union Regulations in the field of pro-ecological activities.

In the light of the direction of the legal changes that have been implemented by the European Union, in particular the Regulation of the European Parliament and of the Council No. 305/2011 on the conditions for introducing construction products, growing pressure to reduce energy consumption in the construction market, transport and the industrial production of materials can be observed. From April 24, 2011, certain provisions came into force,

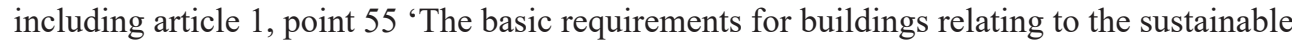
use of natural resources should take into account, in particular, the possibilities of recycling buildings and their demolished materials and parts, the durability of buildings and the use of environmentally friendly raw materials and secondary materials.' From July 1, 2013 Annex I of the Regulation came into force, which in point 7 contains a provision on the sustainable use of natural resources. Construction works must be designed, constructed and demolished in such a way that the use of natural resources is sustainable and ensures the following:

- the reuse or recycling of construction works and their materials and parts after demolition;

- the durability of buildings;

- the use of environmentally friendly raw materials and recyclable materials in the construction of buildings [1].

It should be emphasized that the construction sector in the countries of the European Union is responsible for the consumption of up to $40 \%$ of the energy produced in the EU, which makes it the main source of the extensive carbon dioxide emissions into the atmosphere [5]. In the light of the regulations and directions that have been laid out by the modern economy, environmental problems have reached the scale of a global threat, which is the main reason for the increased interest in natural construction. Construction using straw bale technology utilizes plant-derived materials without burdening the environment in the production process and thus makes then suitable for sustainable construction.

\section{2. $\mathrm{CO}_{2}$ reduction as a determinant of pro-ecological activities}

Carbon dioxide is the main driver of the greenhouse effect; the need to reduce global energy consumption and greenhouse gas emissions is the main reason why technologies that reduce $\mathrm{CO}_{2}$ emissions to the atmosphere are being sought. $\mathrm{CO}_{2}$ is a byproduct from the process of producing electricity and heat caused by the combustion of fossil fuels [6]. The main activity that aims to achieve a reduction in $\mathrm{CO}_{2}$ emissions to the atmosphere is increasing energy efficiency in the construction sector. The policy and activities of the European Parliament aim to reduce carbon dioxide emissions by $90 \%$ compared to 1990 levels. EU Directive 2010/31/EU from 19 May 2010 on the energy performance of buildings [7] states that there must be a reduction in the energy consumption in buildings in the countries of the European community. It also states that by December 31, 2020, all new buildings should have almost zero energy consumption, and from December 31, 2018, buildings intended for use by public authorities and owned by them must also meet this stipulation. Therefore, changes were made in Poland to the regulations on the technical conditions to be met by buildings and their locations, which represent the maximum allowable values of heat transfer coefficients for building partitions and the maximum allowable values of non-renewable primary energy indicators for newly designed buildings [8]. 
The environmental effect of construction activity has an impact on the reduction of raw material resources, including energy carriers and space [5]. Considering the above-mentioned issues and the fact that there is a threat of the depletion of energy resources throughout the world, it is necessary to adopt all the actions that are aimed at improving the spread of pro-ecological technologies, which includes straw bale technology.

\section{Characteristics of natural straw construction}

Contemporary natural construction refers to traditional, historic technologies and is based on local materials that do not require intensive processing. The essence of natural construction is to reduce the negative impact of the construction industry on the natural environment without affecting the comfort, durability and aesthetics of the building. The basis is the use of human labour, without the use of advanced, and thus energy hungry, devices and machines [1].

The main features of straw bale technology include:

- lightly-processed material - clean straw without the addition of construction chemicals;

- $100 \%$ renewable raw material - organic, local material;

- the coefficient of thermal conductivity $\lambda$ for cubes of pressed straw with a density of $85-115 \mathrm{~kg} / \mathrm{m} 3$ and a direction of heat flux parallel to the fibres is $0.080 \mathrm{~W} / \mathrm{mK}$ [9]; for comparison, the value of the $\lambda$ coefficient for aerated concrete blocks $24 \mathrm{~cm}$ is $0.21 \mathrm{~W} / \mathrm{mK}[10]$;

- the heat transfer coefficient $U$ for a wooden wall filled with $50 \mathrm{~cm}$ thick cubes of straw is $0.16 \mathrm{~W} / \mathrm{m} 2 \mathrm{~K}$ [9]; the value of the heat transfer coefficient depends on the width of the straw cube and its arrangement, which ranges from 0.15 to $0.20 \mathrm{~W} / \mathrm{m} 2 \mathrm{~K}$;

- good sound insulation - sound insulation index RW, R=43 dB for a $36 \mathrm{~cm}$ thick wall, plastered on both sides [11];

- minimizing construction waste - biodegradable materials [5];

- good fire resistance of plastered walls (according to British tests 135 minutes or REI 120, according to German tests F90 or REI 90) [12];

- high vapour permeability - prevents the accumulation of moisture inside the walls (diffusion-open walls; straw is a vapour-permeable material, characterized by a coefficient of water vapour diffusion resistance of $\mu=2$ [11];

- a healthy microclimate - the interiors are characterized by moisture regulation, heat accumulation, they bind harmful substances and are anti-static [13].

A building built using straw bale technology displays a combination of durability, with respect for the natural environment, and simplicity with the functionality that is mainly used in single-family housing. The method used to shape the building is determined by the geometry that results from using straw cubes. When designing both the functional and utility system in the case of straw bale technology, the modular distribution of the axes of the structural walls, in relation to the size of the straw cube, should be taken into account.

The supporting structure of such a building is made from wood and filled with straw cubes, most often produced by local factories. The outside of the building is finished with lime plaster, while the inside is covered with clay plaster. In the case of the "straw house project" by architect Michał Koziej, the gable walls and eaves were protected with wooden cladding, the purpose of which is to protect the external plaster against adverse weather conditions. Some applications of straw bale technology in construction site are given in Figs 1, 2 and 3. 


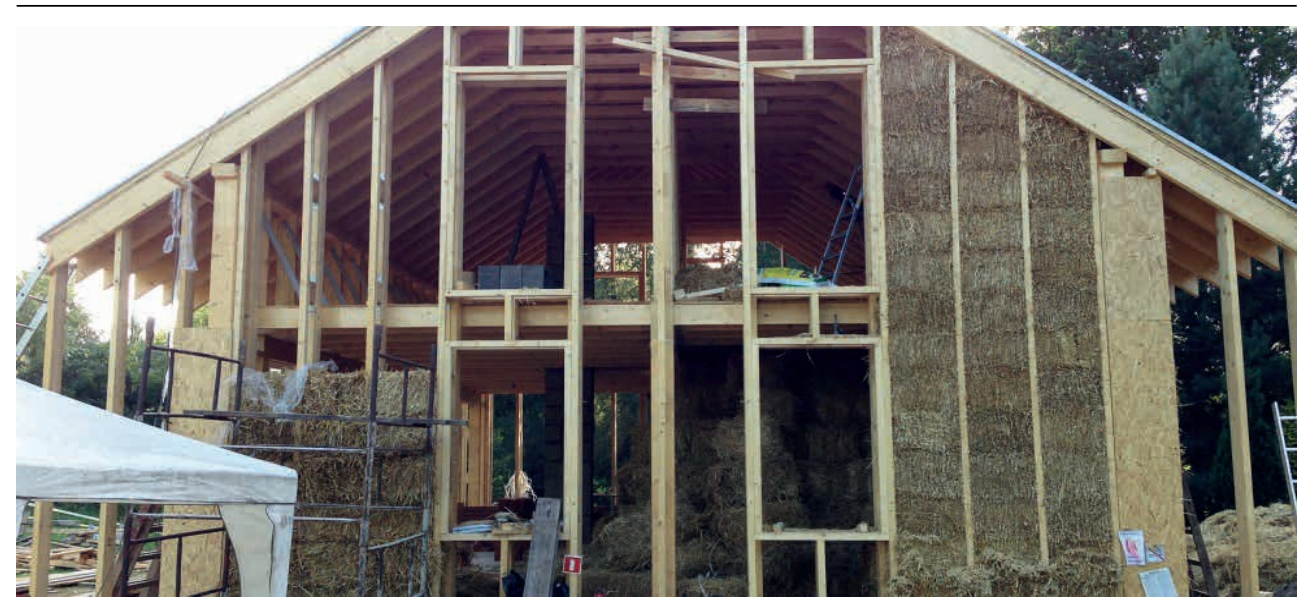

Fig. 1. Implementation of the 'straw house' project 2014/2016, Koziej Architekci office (source [14])

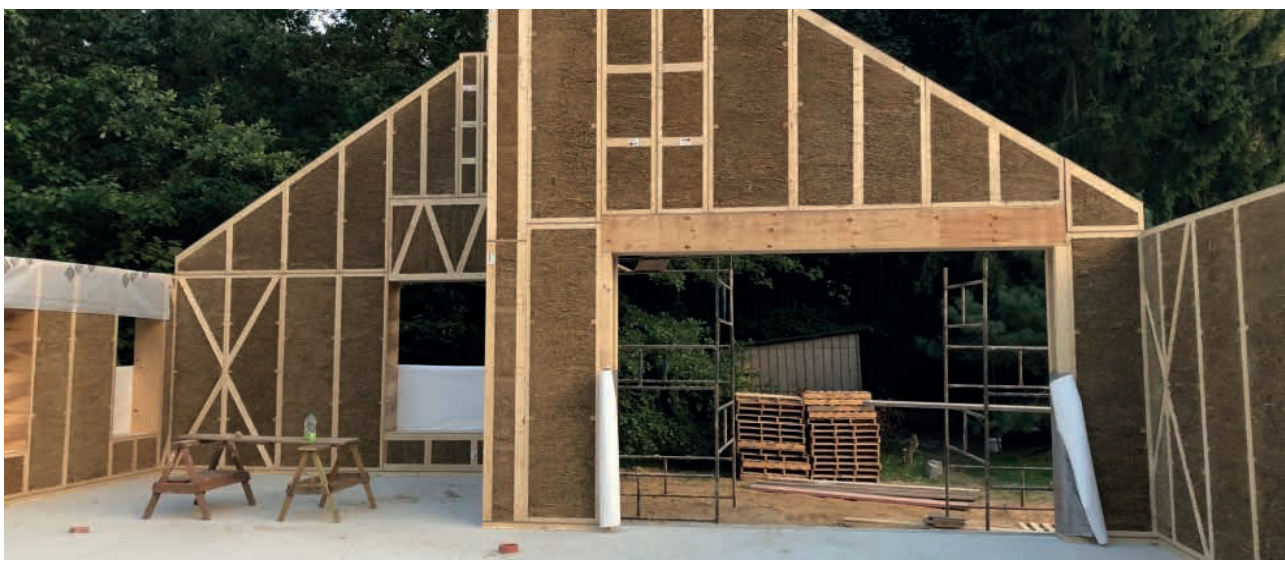

Fig. 2. Implementation of the 'ASZ Dom' project using prefabricated EcoCocon panels, Koziej Architekci office, source: www.koziejarchitekci.com [14]

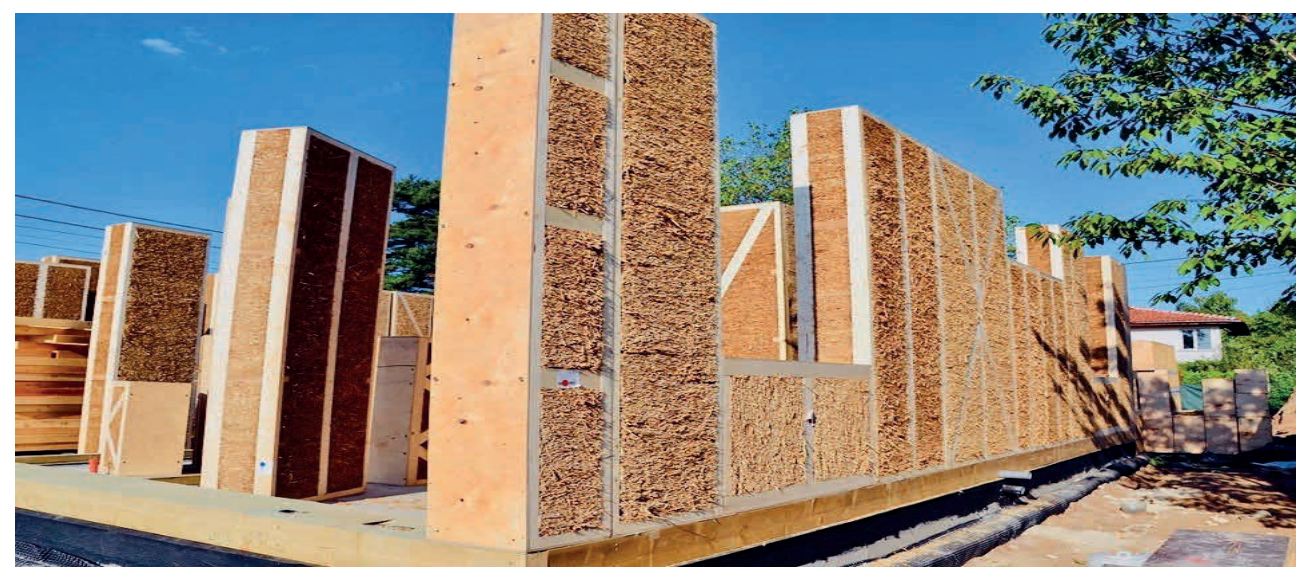

Fig. 3. Walls made of EcoCocon straw panels. Vastu Home - Bulgaria house design, source: www.ecococon.lt 


\section{Opportunities and threats in straw bale technology}

The development of technology for the production of building materials has always focused on modern solutions that use the latest discoveries in a given field. Progress is the natural consequence of technological revolutions, which are not in short supply in the 21 st century. Natural construction requires a new outlook and the adaptation of production, design and implementation solutions to the requirements of modern, innovative construction products. The current state of knowledge indicates that there are opportunities for natural construction using straw bale technology, which are as follows:

1. it is a low-carbon technology that reduces carbon dioxide $\left(\mathrm{CO}_{2}\right)$ emissions; straw production is a low-energy process, compared to the production of other building materials and reduces greenhouse gas emissions; $1 \mathrm{~kg}$ of straw absorbs $1.36 \mathrm{~kg}$ of $\mathrm{CO}_{2} ; 1$ cube of dimensions $40 \times 47.5 \times 100 \mathrm{~cm}$, a density of $121 \mathrm{~kg} / \mathrm{m} 3$ and a weight of $23 \mathrm{~kg}$ absorbs $31.28 \mathrm{~kg} \mathrm{CO}_{2}$ [1]; at the beginning of the process, the production of straw cubes requires the development of plants that have the ability to absorb $\mathrm{CO}_{2}$ in the growth cycle, which in turn translates into negative carbon dioxide emissions [15];

2. the possibility of constructing nZEB and passive buildings; it has very good thermal insulation parameters for the building's walls [15]; a $50 \mathrm{~cm}$ thick wall has a heat transfer coefficient of $\mathrm{U}=0.16 \mathrm{~W} / \mathrm{m} 2 \mathrm{~K}$;

3. it has very good acoustic parameters [15];

4. recycling of buildings made of biodegradable materials; after the use phase of the building, the straw can be processed or biodegraded and can also be used as a raw material to produce energy; in case of the use of prefabricated panels, e.g. ModCell, it is possible to disassemble the building and reuse them [12];

5. opportunities for agriculture and rural development; involvement of the local population and the integration of future residents in the construction process; support for regional suppliers, which in turn will develop the local labour market;

The organic nature of straw, under favourable conditions, demonstrates threats to natural construction using straw bale technology; these primarily include:

1. protection against rot and mould; susceptibility to rot increases with the occurrence of certain thermal and humidity conditions [12]; the design of the connection of the foundation wall with the wall of each storey is particularly important, this will protect against moisture and the migration of moisture from the foundation level; it is also important to ensure the air tightness of the surface layers in order to minimize oxygen access to the partition, as this would significantly accelerate the degradation processes $[9,16]$;

2. the heterogeneity of the raw material for the production of straw cubes, this determines the technical parameters of the straw cat; such as making cubes with good quality straw without signs of mould growth, or infected with diseases [9, 17];

3. difficulty in selecting a computational model that correctly describes the thermal and humidity phenomena that occur and the choice of the material parameters for numerical analysis; to avoid the risk of adopting parameter values that are too optimistic in the calculation model [9];

4. limiting moisture penetration; it is necessary to properly select the plaster using the principle of greater diffusion resistance on the inside of the partition; the external 
plaster should be characterized by high vapour permeability ( $\mathrm{sd} \leq 0.5 \mathrm{~m}$ ) so that moisture could migrate outside in the event of water vapour entering the structure; the internal plaster should have a vapour barrier layer $(\mathrm{sd} \geq 0.1 \mathrm{~m})$ in order to limit the penetration of moisture inside the partition; these requirements will be met when $3 \mathrm{~cm}$ thick internal plaster $(\mathrm{sd}=0.3 \mathrm{~m})$ and $3 \mathrm{~cm}$ thick external plaster $(\mathrm{sd}=0.45 \mathrm{~m})$ are used $[9,11]$;

5. the threat of bad weather conditions during construction; the partitions should be protected by using eaves or ventilated external facades [9];

6. low social awareness of straw bale technology;

7. fire resistance; clean straw is flammable, however, in the production process of pressed straw cubes or prefabricated panels, the fire resistance increases; ModCell prefabricated panels have a fire resistance certificate for 2 hours; in the laboratory of the University of Bath, panels were subjected to a fire test which lasted for 2 hours and 15 minutes (temperature $1000^{\circ} \mathrm{C}$ ); after 90 minutes, the lime plaster covering the panel was destroyed; carbonization of the exposed straw occurred after further 45 minutes [12];

8. difficulty in assessing the degradation of the straw within a cube during the lifetime of the building; the humidity level inside the partition was tested using sensors located in the wall to record the changes in the humidity levels that occur during the lifetime of the facility [15]; studying this phenomenon is important because of the adverse effect of moisture penetration on the straw;

9. protection against rodents; straw has little nutritional value and is not of interest to pests, and the use of plaster layers significantly reduces the ingress risk of harmful organisms [12].

\section{Conclusion and forecast for the future}

The direction of the future development of the construction market lies in innovative pro-ecological activities; these take into account energy consumption, recycling processes, durability of buildings and building life cycles [18]. Technologies are being sought that guarantee that the growing demand for materials that are hygrothermal, future-proof and at the same time biodegradable can be met. The natural environment must be cared for and this drives innovation; this presents a challenge for modern natural construction. Although some of the perspectives that have been indicated, e.g. the production of load-bearing panels [19] have been implemented, they are still lone initiatives that have been targeted at local recipients and do not constitute a coherent development policy. It is also necessary to introduce legal regulations that will drive the development of this promising branch of natural construction.

As a result of this study, the following subjects can be highlighted as the most important and up to date perspectives for the development of straw bale technology:

- the development of technology for the construction of prefabricated load-bearing panels,

- standardization of solutions (repeatability of both the properties and technical parameters of the straw cubes) [20],

- cataloguing of the basic design solutions,

- making the construction process independent of weather conditions, 
- information and educational campaigns, including cooperation with research institutions,

- a study of the earthquake resistance of straw cubes, as well as their absorption of seismic vibrations,

- implementation of the technology for multi-family buildings, collective housing and public utilities,

- monitoring existing buildings [21].

\section{References}

[1] Zatylny M., Uwarunkowania formalno-prawne dla budownictwa naturalnego w Europie i Polsce ze szczególnym uwzględnieniem zastosowania kostek słomy. Project: "Zintegrowany System Wsparcia Ekonomii Społecznej”.

[2] Gradziuk P., Gospodarcze znaczenie i możliwości wykorzystania słomy na cele energetyczne w Polsce. Instytut Upraw Nawożenia i Gleboznawstwa, Państwowy Instytut Badawczy, Monografie i rozprawy naukowe, vol. 45, Puławy 2015.

[3] Nowak M., Kołaczkowski M., "Nowy wymiar budownictwa ze słomy", Czasopismo Techniczne, Budownictwo 4-B (28) 2015, pp. 107-114. https://doi.org/10.4467/2353737XCT.15.407.5038

[4] Walkowska K., Cierpiał-Wolan M., Gospodarka materiałowa w 2017 r.. Główny Urząd Statystyczny, Rzeszów 2018.

[5] Adamczak J., Dylewski R., "Recykling odpadów budowlanych w kontekście budownictwa zrównoważonego", Problemy ekorozwoju, vol. 5, no 2, 2010, pp. 125-131.

[6] Kotowicz J., Janusz K., "Sposoby redukcji emisji $\mathrm{CO}_{2}$ z procesów energetycznych”, Rynek Energii, no. 1, 2007, pp. 10-18.

[7] Directive 2010/31/EU of the European Parliament and of the Council of 19 May 2010 on the energy performance of buildings. Available: https://eur-lex.europa.eu/eli/dir/2010/31/oj [Access: 12 Jan 2020]

[8] Alsabry A. et al., "Analiza wpływu wybranej metodologii oceny mostków cieplnych na bilans energetyczny budynku", Budownictwo i Architektura, vol. 17(1), 2018, pp. 157-168. https://doi. org/10.24358/Bud-Arch_18_171_19

[9] Noszczyk P. et al., "Wybrane problemy budownictwa ze słomy", Fizyka budowli w teorii i praktyce, vol. VIII, no.2, 2016, pp. 29-34.

[10] Pawłowski K., "The analysis of energy-saving technologies used in buildings with low energy consumption", Budownictwo i Architektura, vol. 18(3), 2019, pp. 5-16. https://doi. org/10.24358/10.35784/bud-arch.563

[11] Fachverband Strohballenbau Deutschland e.V. Strohbaurichtlinie SBR-2014, FASBA, Verden 2014

[12] Golański M., "BaleHaus - eksperymentalny budynek z prefabrykowanych paneli modularnych ModCell”, Przeglad Budowlany, no. 12/2012, pp. 74-79.

[13] Backiel-Brzozowska B., "Budownictwo z gliny i słomy - wstępna ocena wybranych aspektów trwałości”, Inżynieria Ekologiczna, vol. 40, 2014, pp. 208-216. https://doi.org/10.12912/2081139X.83

[14] Michał Koziej, Dom ze stomy. Available: http://www.koziejarchitekci.com/prace-works/3,domze-slomy-strawbale-house.html [Access 24 Nov 2019]

[15] Lawrence M., Heath A., Walker P., "Monitoring of the Moisture Content of Straw Bale Walls", in Proceedings of the International Conference in Sustainability in Energy and Buildings (SEB’09) 2009. Howlett R.J, Jain L.C., Lee S.H. (eds), Sustainability in Energy and Buildings. Springer, Berlin, 2009. https://doi.org/10.1007/978-3-642-03454-1_17

[16] Yin X., Lawrence L., Maskell D., Chang W., "Construction and monitoring of experimental straw bale building in northeast China", Construction and Building Materials, vol. 183, 2018, pp. 46-57. https://doi.org/10.1016/j.conbuildmat.2018.05.283 
[17] Sabapathy K., Gedupudi S., "Straw bale based constructions: Measurement of effective thermal transport properties", Construction and Building Materials, vol 198, pp. 182-194, 2019. https:// doi.org/10.1016/j.conbuildmat.2018.11.256

[18] Marques B. et al., "Characterisation of sustainable building walls made from rice straw bales", Journal of Building Engineering, vol 28, 2020, 101041. https://doi.org/10.1016/j.jobe.2019.101041

[19] EcoCocon, Meet the Panel - the Building Block of the Future. Available: www.ecococon.1t [Access: 23 Nov 2019]

[20] Beaudry K., MacDougall C. "Structural performance of non-plastered modular straw bale wall panels under transverse and gravity loads", Construction and Building Materials, vol. 216, 2019, pp. 424-439. https://doi.org/10.1016/j.conbuildmat.2019.04.186

[21] Yin X., Lawrence L., Maskell D., "Straw bale construction in northern China - Analysis of existing practices and recommendations for future development", Journal of Building Engineering, vol 18, 2018, pp. 408-417. https://doi.org/10.1016/j.jobe.2018.04.009 
